\title{
Experimental Research: The Effectiveness of Card Game Learning Media in Learning Shorof Arif Humaini
}

\author{
Universitas MuhammadiyahYogyakarta, Indonesia \\ Corresponding E-mail: arifhum@umy.ac.id
}

\begin{abstract}
The word 'media' comes from the Latin Language 'medium'. Media is a means of the instrument to channeling messages or learning information, by using the media can help achieve learning success. A media is very urgent and important in the effort to achieve the learning objects of the material. Learning media that is interesting for learners of Arabic is very needed, especially in understanding the material of Arabic rules. As we know that in Arabic Language Grammarly 'Shorof' which requires a lot of memorization. According to that as a solution is to use game as card for learning media. This learning media found in many learning process. But it has never been applied to the 'Shorof' material. This research was tried to experiment with its effectiveness to students of the Arabic Language Education Study Program in Faculty of Language Education, Universitas Muhammadiyah Yogyakarta. The long-term need of this research is to provide a solution or a way to facilitate Arabic learners in memorizing the rules of 'Shorof' material in Arabic language and find effective learning media solutions in teaching Arabic in general.
\end{abstract}

Keywords: Arabic language, card, media, shorof.

\section{INTRODUCTION}

There are four things in language skill, those are speaking, listening, reading and writing. Writing and reading really need ability in grammar or rules of language which in Arabic known as Nahwu and Shorof. Nahwu is the rule of syntax which learn about the ending of harakat from each word in a sentence that related with the position from each word then it has arranged become a whole sentence. On the other hand, Shorof is the rule of morphology that discusses the changing of the word from the origin. There are some rules of Shorof in Arabic that should be memorized. It should be noticed in giving the Shorof learning material that the material should be interesting and easy in memorizing.

Many people assume that learning Arabic is very difficult even in Indonesia Moslem is the majority and almost all the Moslem people have been learned Arabic since early when they starting to learn to read Al Quran which in Arabic form. Based on Fathi Ali Yunus's research that conducted at Mesir in 1977, "almost all the responder said that Arabic is difficult because the society believes that Arabic is difficult to learn even it has been practiced in decades". .. It is seen

\footnotetext{
${ }^{1}$ Muhbib Abdul Wahab, Metode Penelitian dan Pembelajaran Nahwu: Studi Teori Linguistik Tammam
}

that many people still assumed that learning Arabic is difficult, moreover in Mesir that geographically near from origin of Arabic and of course near from the native speaker. Therefore, we should found the solution in order to decrease the assumption form many people that learning Arabic is difficult. The solutions to cover that problem are by using appropriate and interesting learning method. Nowadays, Arabic learning method that develops is focused on creative and innovative aspects which come from constructive learning theory, not only the teacher as the prominent source but also another media as the study source. Recently, a card becomes the popular Arabic learning media with a picture or smart card, but the newest is learning media by using the online system.

Wa Muna wrote in a journal ${ }^{2}$ and he explained that game card is one of the conceptual media because this media can bring the students in the real of learning context indirectly. The message from the game is a form of verbal expression in pieces of paper. This media is cheap and flexible. It only needs a piece of carton or thick paper

Hassan, (Jakarta: PPs UIN Syarif Hidayatullah Jakarta, 2008), 1

${ }^{2}$ Wa Muna, Kartu Permainan: Media Pembelajaran Bahasa Arab Kontekstual. Jurnal Al-Ta'dib Vol. 7 No. 1 Januari-Juni 2014. Page. 89 
and pen/ marker then it can bring to wherever we will use. There are some kinds of this game, but there only 10 kinds of game card that can be told, those are: (1) question and answer card (Bithoqah al As-ilah wa alijabah). (2) refinement card (Bithoqah al Takmilah). (3) Vocabulary card (Bithoqah al mufradat). (4) Imitation card (Bithoqah al mushoghor)" 3 (5) stick figure card (bithoqah tashwir al yadi) (6) arrange word card (Bithoqah tarkib al mufradat). (7)a pin card (8) picture change card (9) board speaker (10) find my couple) " ". .

The concept of Arabic learning by using card media often found in the implementation of Arabic learning that mostly to enhance vocabulary comprehension. It likes research that conducted by Hilmi, stated that the use of colorful picture/photo makes the students interesting in learning then It can increase their motivation and their attention in learning Mufradat. When their motivation and attention increase, the students will concentration with the material discussed. ${ }^{5}$ In this research, we will try not only using a card for Mufradat, but also as media for memorizing Shorof material. Some of the material in Shorof poring and writing in the colorful card that packing informs a game so that it interesting.

Therefore this research tries to conduct an experiment to prove the effectiveness of Arabic learning method by using card media to enhance the understanding and memorizing the rules of Shorof easily. The object of this research is the student of Arabic Education from Language Faculty of Muhammadiyah Yogyakarta University.

\section{THEORETICAL BACKGROUND}

\section{The Definition of Learning Method}

The word "media" comes from Latin that in plural form is "medium", literally it means intermediary or introduction, which

\footnotetext{
${ }^{3}$ Abdul Wahab Rosyidi, Media Pembelajaran Bahasa Arab, Malang: UIN Malang Press, 2009. Page. 69-72

${ }^{4}$ Fathul Muib dan Nailur Rahmawati, Metode Permainan Edukatif dalam belajar Bahasa Arab, Jogjakarta: DIVA Press, 2011, Page. 79, 85, 88, 103, 105

${ }^{5}$ Hilmi, Efektivitas penggunaan media gambar dalam pembelajaran bahasa arab Lantanida Journal, Vol. 4 No. 2, 2016. Page. 133
}

is an introduction between sender and receiver message. In Arabic media called as wasa'il that means the intermediary or sender from the receiver message. ${ }^{6}$

Gerlach \& Ely (1971) stated that media is understood as human, material or incident that can build a condition that makes the students can get knowledge, skill or attitude. From the definition, it can be stated that the teacher, textbook and school environment are the media. Especially, media in teaching learning process more inclined meant as tools of graphics, photographics or electronics for catching, processing and arranging back the visual and verbal information. ${ }^{7}$

Generally, here is the limitation of the understanding of learning media: ${ }^{8}$ Learning media has physical definition, nowadays it is known as hardware (2) Learning media has nonphysical definition and known as software that is containing a message in the hardware which is delivering to the students(3) the emphasis of education media is on visual and audio (4) Education media has defined as a tool for helping the study process in the class or outside the class(5) Education media is used in communication, teacher interaction and student in the learning process. (6) Education media can be used massively (examples: radio, television), big group

\footnotetext{
${ }^{6}$ Jepri Nugrawiyati, media audio-visual dalam pembelajaran Bahasa arab, El-Wasathiya: Jurnal Studi Agama. Page. 98

${ }^{7}$ Azhar Arsyad, Media Pembelajaran (Jakarta : Rajagrafindo Persada, 2012). Page. 3

${ }^{8}$ Ibid. Page. 6
} 
and small group (examples: film, slide, video, OHP) or individual (examples: module, computer, tape recorder, video recorder) (7) Education media has a definition as attitude, action, organization, strategy and management that related with the implementation of knowledge.

\section{The Characteristic of Learning Media}

If we seen from the characteristic of learning media itself, Gerlach \& Ely (1971) stated that there are three characteristics of learning media as the instruction why the media is used and what are the advantages of the media so it can help the teacher doing the learning process besides the teacher position as the prominent learning media. The characteristics are $^{9}$

1. The fixative characteristic; the ability in recording, saving, conserving and reconstructing an event or object. An event can be retraced with the photography media, video, computer, film etc. Therefore, this media is possible to record an incident or object that happen sometime and transported without knowing the time.

2. Manipulative characteristic; it possible to manipulate time, an event that happens every day is possible to show in short duration it can in some minutes by catching the picture technique time-lapse recording, for example,

\footnotetext{
${ }^{9}$ Ibid. Page. 15-17
}

lecture recording or another event that can be cut in some parts which we need without showing the whole of the video. These media need an earnest ability because if there is a mistake it will be fatal and effect to the tracing of an event that will show in video, film, slide and etc.

3. Distributive characteristic; it possible to spread or distribute a learning media which only had by a class, education institution or another part that need the same media, so all the circle that in the same level or has relation can feel a new experience that relatives same. For example, the distribution of video recording media or audio and etc that spread to another school that needs it.

\section{The Kinds of Learning Media}

There are some kinds of learning media: $:^{10}$

1. Audio media; all the things that can be used for making the language learning easier that can be caught and dissolved by listeners' sense. For example language, tape recorder, radio transistor, television, language laboratory, and etc.

2. Visual media; all the things that can be used for making the

${ }^{10}$ Acep Hermawan, Metodologi Pembelajaran Bahasa Arab. (Bandung : Rosda, 2014). Page. 227 
language learning process easier that can be caught and dissolved by using the sense of sight. For example, the original object, imitation object, picture, board, announcement board, flannel board pouch board, stick figures (picture that directly made by the teacher), strip story, flash card, textbook, bulletin, slides projector, OHP, computer, LCD projector, and etc.

3. Audio-visual media; all the things that can be used for making the language learning process easier that can be caught and dissolved by using listener's sense and sight. For example, television, CD video, cinema, multimedia language laboratory, LCD projector, internet and etc.

\section{The Function and the Advantages of Learning Media}

Based on Hamalik (1986), he stated that the use of learning media in the teachinglearning process can generate new interest, motivation, and stimulation of learning activity, moreover it can bring psychology influences to the students.

The used of learning media in the learning orientation phase will really help the effectiveness of the learning process and the explanation of the message and the content of the lesson at that time. Besides generating the motivation and the students' interest, the use of learning media also can be helped the students in increasing their understanding, presenting the data by the interesting way and believable, interpreting the data easily, and tamping the information. ${ }^{11}$

Levie \& Lentz (1982) stated that there are four functions of learning media, especially visual media, those are: ${ }^{12}$

1. Attention; interesting and directing the students' attention to make them concentration with the content of the lesson which related to the visual meaning that shown or accompanying the lesson material.

2. Affective; make the student feel more enjoy when they study to read the text with the picture. Picture or visual symbol that inspiring emotion and student' attitude, for example, an emotion that involving social or race.

3. Cognitive; Smoothen the aim target for understanding and remembering the information or message in the picture.

4. Compensatory; visual media that giving the context for understanding the text, helping the students that weak in reading for organizing the information in the text and remembering it again.

Furthermore, Sudjana dan Rivai (1992) stated that there are some advantages of learning media in students learning process, those are: (a) can grow the students' learning motivation because the teaching process can

\footnotetext{
${ }^{11}$ Azhar Arsyad, Media Pembelajaran. ( Jakarta : Rajagrafindo Persada, 2016). Page. 19

12 Ibid. Page. 20
} 
make them more interesting (b)the meaning of teaching material clearer so can be understood easily, it will be mastered and the goal target will be achieved. (c) teaching method will more variation, it not based on the verbal communication by words (d) the students doing more activity during the study activity, it not only listening but also observing, demonstrating, directly doing and practicing.

\section{Learning Media by Using Card Game}

Learning media by using card game is adopted as learning media, which aim to help the students in understanding moreover mastering the lesson material. An interesting thing where the students feel enjoy in studying because it packing with the game.

In some research sources, card game as learning media not only applied in enhancing the understanding to the lesson material or one of discipline knowledge but also it can be used flexibly and another discipline knowledge such IPA, IPS moreover religion lesson appropriate with the learning need. In the language learning, card media that often use is media "picture card" which most of them focuses on the learning and aim to enhance the understanding and mastering vocabulary.

There are some kinds of card media, those are:

1. The short card is media in the form of cards that made by manila paper with the size $8 \times 8 \mathrm{~cm}$ which there are some kinds of alphabet and number or word in the top. From some literature, the short card also called flash card and picture card. Basuki Wibawa and Farida Mukti (1991:30) stated that flash card contains words, picture or the combining and can be used for developing vocabulary. ${ }^{13}$ Flashcard (remembering card) is a card that shown a glance to the students. The size depends on how big the class is. For example, if the class big, it uses $25 \times 20$ $\mathrm{cm}$. The cards are drawn or given a symbol for instructing or stimulating the students to think or do a. ${ }^{14}$

2. A card sort is a learning model that did collaboratively. This mode can use to teach the concept, characteristics, classification and the real object or reviewing the material that has been discussed in the previous learning. The domination of the physical movement in the implementation of this mode help in turning on the class atmosphere. ${ }^{15}$

3. Index card match is a number of a card with $10 \times 4 \mathrm{~cm}$ that uses in pairs. These cards consist of two colors, for example, blue for the card that consists of vocabulary of Indonesian vocabulary, and the white color consists of Arabic. Then the students asked to play and pair

\footnotetext{
${ }^{13}$ Rita Fita Lestari. 2013. Pengaruh Media KartuBergambarterhadapHasilBelajar IPS padaSiswaKelas IV SDN Kotagede 5 Yogyakarta TahunAjaran 2012/2013. Prodi

PendidikanPraSekolahdanSekolahDasar.FakultasIlmuP endidikan. Universitas Negeri Yogyakarta.

${ }^{14}$ Acep Hermawan, Metodologi Pembelajaran Bahasa Arab.( Bandung : Rosda, 2014). Page. 5

${ }^{15}$ Muhammad Faturrohman,Model-model

Pembelajaran. (Yogyakarta :Ar-ruz Media, 2015). Page. 196
} 
the cards between the white card and

the other card on the top. ${ }^{16}$

\section{The Basic Idea of Shorof Card Learning}

\section{Media.}

In choosing the learning media, we should pay attention to these points: 1) the accuracy of the aim of the learning; 2) the relevance of the learning contain 3) the easiness in getting the media 4) the teacher creativity in using the media 5) the available time to use the media 6) it appropriate with the students' level of thinking. By these criteria, the teacher can determine the appropriate media in helping to do their task easily. But, the presence of media in the learning process do not be forced, because it can make the teacher difficult, it must be facilitated the teacher in delivering the material easily. ${ }^{17}$

The Shorof learning is implemented with this game card that inspired from the previous research that conducted on 2016 by PSPDG (Program Studi Pendidikan Dokter Gigi) UMY 2012 by the title Perbandingan Hasil Belajar Mahasiswa Sebelum dan Sesudah Proses Belajar Aktif Menggunakan Kartu Anatomi Gigi (KABANOGI) (Kajian pada Mahasiswa Angkatan 2014 Program Studi Pendidikan Dokter Gigi di Universitas

\footnotetext{
${ }^{16}$ Sri DewiAstuti. 2013. Pengembangan Media KartuPintardalamPembelajaranKosa Kata Bahasa Arab (StudiKasus di Kelas VIII

MTsNPiyungan).FakultasIlmuTarbiyahdanKeguruan.U IN SunanKalijaga.Skripsi

${ }^{17}$ Wakhidati Nurrohmah Putri, Pengaruh Media Pembelajaran Terhadap Motivasi Belajar Bahasa Arab Siswa Madrasah Tsanawiyah, Lisania: Journal of Arabic Education and Literature Vol.1, No.1, 2017. Page. 8
}

Muhammadiyah Yogyakarta) where this research become the morphology tooth learning with the smart card KABANOLOGI (The Anatomy of teeth) to the PSPDG 2014.

Based on the transformative generativism by Noam Chomsky, he assumed that the learning language is a process of forming the rule not habitual, then he argued that the object of language is about the cognition or children knowledge, knowledge that possible to understanding and changing a sentence become another sentence in the turn will bear any new sentence. The ability to transform one sentence becomes another sentence in the turn will bear a language so it demands the teacher to more creative in developing the students' language ability. ${ }^{18}$ Wherefore, in the learning process, the teacher must creative and transformative in developing students' language ability, so card media as the one of the solution and transformation in learning language related with the rule and language theory.

Constructing Shorof card also can use a principle that the acquisition of knowledge and creativity, the changing of attitude and behavior can happen because of the interaction between the new experience with the experience that ever been experienced. ${ }^{19}$ Thus it hopefully by using the Shorof card as the learning media, the students will found a new experience that is learning by a new way which form of learning

\footnotetext{
${ }^{18}$ Mahyudin, dan Aziz Fachrurrozi,

PembelajaranBahasaAsingTradisional \& Kontemporer. (Jakarta : RajagrafindoPersada, 2016). Page. 28, dan 31 ${ }^{19}$ AzharArsyad. 2016. Media Pembelajaran. Jakarta :RajagrafindoPersada. Page. 10
} 
while playing the game and it related with the previous experience that is giving the material that has been given before.

According to Bruner (1966), there are main levels or steps learning modus, those are (1) direct experience (inactive)(2) pictorial experience (iconic) (3)abstract experience (symbolic). The meaning of direct experience is doing an activity, for example in getting the word "node" it directly understood as making node. In the next level, it labeled as iconic (picture/image), the word "node" is studied from picture, paint, photo or film. Even though the students are never binding to make a node, they can learn and understand it from the picture, paint photo or film. Next, the level of symbol, the students read (listen) the word "node) and try to match it with their experience in making node. Based on the three levels above, there are interaction activities in getting a new 'experience' (knowledge, creativity or attitude). ${ }^{20}$

On the other hand, Dale (1969) three levels experience in getting the result of study above is a communication process. In his book "Audio-visual methods in teaching", Edgar Dale make a classification according to the level from the most concrete to the most abstract, which known as "the experience cone."

Hopefully, the material that is delivered to the students can be understood and mastering and it called a message. Teacher as the message source is pouring a message in form of symbols (encoding) and

\footnotetext{
${ }^{20}$ Ibid
}

the students as the receiver of the message can interpret it, so it can be understood as the message (decoding). ${ }^{21}$

Brunner dan Dale theory is become one of the bases in making the card and not rule out the education as the main reference.

\section{METHOD}

This research used a quantitative approach with the pre-experimental research and the design is one group pretest-posttest. A quantitative approach is an approach that learns about the surface problem or the outside part, then it tends to atomistic or solves the real of the parts, finding the relation between the limitation variable. It aims to find the generalization that use to predict. Besides that, it also tends to deterministic that focus on the certainty to test the hypothesis. ${ }^{22}$

The research design that used one group pre-test post-test design is research design that the group not taken in a random or pair, it also there is no comparison group, but it will give pretest and posttest besides the treatment. ${ }^{23}$ The use of the test is aim to measure whether there is or not the ability of the object that is examined and the dimensions. The instrument used to measure the bases of the ability and achievement. ${ }^{24}$ The

\footnotetext{
${ }^{21}$ Ibid. Page. 11

${ }^{22}$ Syamsuddin AR \& Vismaia S. Damaianti, Metode Penelitian Pendidikan Bahasa. (Bandung : Rosda, 2015). Page. 31, dan 33

${ }^{23}$ Nana Syaodih Sukmadinata, Metode Penelitian Pendidikan. (Bandung : Rosda, 2012). Page. 208

${ }^{24}$ Suharsimi Arikunto, Prosedur Penelitian : Suatu Pendekatan Praktik.(Jakarta : Rineka Cipta, 2013). Page. 226
} 
test used twice, those are before and after the treatment or pre-test dan post-test.

Then for knowing the effectiveness, Soetomo (1993) stated that the effectiveness can be meant in so far the things that have been planned can be done. If the result shows the percentage is big or not far from the plan, so it can be said that it effective. Otherwise, if the result is far from the plan, it can be said that it not effective. ${ }^{25}$ In the implementation, effective learning is a thing that certifies in completing the goal of the learning that marked with the achievement of the learning competency after the learning.

Whereas, Hidayat (2008) and Wahab (2008), both of them agreed that an activity can be said effective if there is an effect from the activity and it can bring a result or effect to the students in the process or the result.

Then, for measuring the effectiveness it used t data analysis technique. The t-test is the calculation for knowing the effectiveness of this game card media when it implemented to the learning Shorof by the formula: ${ }^{26}$

Explanation:

$$
T=\frac{\mathrm{Md}}{\frac{\sqrt{\sum X^{2} \mathrm{~d}}}{\mathrm{~N}(\mathrm{~N}-1)}}
$$

Md : mean from the differences between pre-test and post-test

$X_{d}:$ deviation from each subject (d - Md)

$\sum X^{2} d$ : the total of deviation quadrate

$\mathrm{N} \quad$ : subject on the sample

d.b : decided by N-1

\section{RESULT AND DISCUSSION}

\footnotetext{
${ }^{25}$ Mahyudin, dan Aziz Fachrurrozi, Pembelajaran Bahasa Asing Tradisional \& Kontemporer. (Jakarta : Rajagrafindo Persada, 2016). Page. 206

${ }^{26}$ Ibid. Page. 351
}

This research conducted in March until April 2018. The composition of the data population as the sample from the research can be explained on the table below:

\begin{tabular}{|c|c|c|}
\hline Composition & Total & Explanation \\
\hline Population & 34 & $\begin{array}{l}\text { - } 18 \text { students with } \\
\text { class A } \\
\text { background } \\
\text { - } 17 \text { students with } \\
\text { class B } \\
\text { background on } \\
\text { the second } \\
\text { semester } \\
\text { - The population } \\
\text { were } 34 \text { students } \\
\text { that active in the } \\
\text { class, } 1 \text { student } \\
\text { cannot follow } \\
\text { until the end of } \\
\text { the research }\end{array}$ \\
\hline $\begin{array}{l}\text { The sample of } \\
\text { the research }\end{array}$ & 17 & $\begin{array}{l}\text { - } 9 \text { students with } \\
\text { class } \\
\text { background } \\
\text { - } 8 \text { students with } \\
\text { class } \\
\text { background }\end{array}$ \\
\hline $\begin{array}{l}\text { The sample of } \\
\text { the treatment }\end{array}$ & 17 & $\begin{array}{l}\text { - } 8 \text { students with } \\
\text { class } \\
\text { background } \\
\text { - } 9 \text { students with } \\
\text { class } \\
\text { background }\end{array}$ \\
\hline
\end{tabular}

instrumented in the treatment contains 49 questions of Shorof material with the composition:

\begin{tabular}{|l|l|}
\hline Chapter of discussion & $\begin{array}{l}\text { The Total of the } \\
\text { Questions }\end{array}$ \\
\hline Tashrif & 7 \\
\hline The kinds of Fi'il & 7 \\
\hline Dlamir with the fi'il & 7 \\
\hline Tashrif Ishtilahiy & 7 \\
\hline $\begin{array}{l}\text { The harakat formula of } \\
\text { wazan tashrif tsulatsi } \\
\text { mujarrad 6 chapters }\end{array}$ & 7 \\
\hline Tashrif Lughawiy & 7 \\
\hline Mudloro ah alphabet & 7 \\
\hline Total & $\mathbf{4 9}$ \\
\hline
\end{tabular}

1. The result of pre-test

The result of the pre-test is presented in the table below: 


\begin{tabular}{|l|l|}
\hline Category & Score \\
\hline Average & 14,00 \\
\hline Minimal & 3 \\
\hline Maximal & 22 \\
\hline Median & 14,00 \\
\hline Modus & 14 \\
\hline Standard Deviation & 5,788 \\
\hline
\end{tabular}

\begin{tabular}{|l|l|l|}
\hline $\begin{array}{l}\text { Enough } \\
(11,106 \leq \mathrm{X}\end{array}$ & 6 & 35,3 \\
$<16,894)$ & & \\
\hline $\begin{array}{l}\text { Bad } \quad(5,318 \\
\leq \mathrm{X} \quad<\end{array}$ & 2 & 11,8 \\
$11,106)$ & & \\
\hline $\begin{array}{l}\text { Very Bad } \\
(\mathrm{X} \quad \leq\end{array}$ & 2 & 11,8 \\
$5,318) \quad$ & \\
\hline
\end{tabular}

The scores above can be interpreted appropriately with five categories of cognitive and knowledge that reached based on the gain of the score below:

\begin{tabular}{|l|l|}
\hline Category & Score \\
\hline Very Good & $\mathrm{X} \geq \mathrm{M}+1,5 \mathrm{SD}$ \\
\hline Good & $\mathrm{M}+0,5 \mathrm{SD} \leq \mathrm{X}<\mathrm{M}+1,5 \mathrm{SD}$ \\
\hline Enough & $\mathrm{M}-0,5 \mathrm{SD} \leq \mathrm{X}<\mathrm{M}+0,5 \mathrm{SD}$ \\
\hline Bad & $\mathrm{M}-1,5 \mathrm{SD} \leq \mathrm{X}<\mathrm{M}-0,5 \mathrm{SD}$ \\
\hline Very Bad & $\mathrm{X} \leq \mathrm{M}-1,5 \mathrm{SD}$ \\
\hline
\end{tabular}

(Source: Azwar, 2011:163, cit Ria Fitri Lestari 2012)

$$
\begin{aligned}
& \text { Explanation: } \\
& \mathrm{M} \quad=\text { Mean } \\
& \mathrm{SD} \quad=\text { Standard deviation }
\end{aligned}
$$

The result of the interpretation pre-test score

\begin{tabular}{|c|c|c|c|}
\hline Category & Frequency & Percentage & category with the highest frequency and \\
\hline $\begin{array}{l}\text { Very Good }(\mathrm{X} \\
\geq 22,682)\end{array}$ & - & - & percentage were 7 students and in the amount \\
\hline $\begin{array}{lr}\text { Good } & (16,894 \\
\leq X & < \\
22,682) & \end{array}$ & 7 & 41,2 & $\begin{array}{l}\text { of } 41,2 \text {, whereas the lowest score was gained } \\
\text { by the very bad with the frequency and }\end{array}$ \\
\hline $\begin{array}{l}\text { Enough } \\
(11,106 \leq X \\
<16,894)\end{array}$ & 6 & 35,3 & $\begin{array}{l}\text { percentage were } 2 \text { students and in the amol } \\
\text { of } 11,8 \text {. }\end{array}$ \\
\hline $\begin{array}{lr}\text { Bad } & (5,318 \\
\leq X & < \\
11,106) & \end{array}$ & 2 & 11,8 & $\begin{array}{l}\text { 1. The result of the Post-test } \\
\text { The post-test activity conducted after the }\end{array}$ \\
\hline $\begin{array}{l}\text { Very Bad }(X \\
\leq 5,318)\end{array}$ & 2 & 11,8 & experiment by using Karf game media, for \\
\hline Category & Frequency & Percentage & knowing the position of the research after \\
\hline $\begin{array}{l}\text { Very Good } \\
(X \geq 22,682) \\
\end{array}$ & - & - & giving the treatment, the situation that scored \\
\hline $\begin{array}{l}\text { Good } \\
(16,894 \leq X \\
<22,682) \\
\end{array}$ & 7 & 41,2 & $\begin{array}{l}\text { was the cognitive ability. The result of the } \\
\text { post-test is presented in the table below: }\end{array}$ \\
\hline
\end{tabular}
appropriate with the 5 cognitive categories that presented in the table below:

presented in form of histogram below:

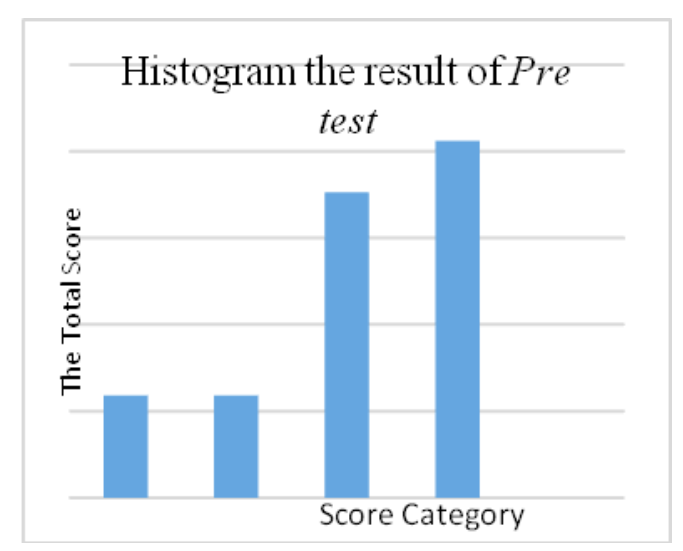

Based on the table, the result of the interpretation of pre-test score and the histogram above, it seen that students' cognitive domain to the Shorof before giving the treatment of Shorof with the Karf game media, the highest score gained in the god category with the highest frequency and percentage were 7 students and in the amount gained percentage were 2 students and in the amount of 11,8 . The post-test activity conducted after the , for nnowing the position of the research after giving the treatment, the situation that scored post-test is presented in the table below: 


\begin{tabular}{|l|l|}
\hline Categories & Score \\
\hline Average & 18,94 \\
\hline Minimal & 14 \\
\hline Maximal & 23 \\
\hline Median & 18,86 \\
\hline Modus & 18 \\
\hline Standard Deviation & 2,487 \\
\hline
\end{tabular}

\begin{tabular}{|l|l|l|}
\hline Categories & Frequency & Percentage \\
\hline $\begin{array}{l}\text { Very Good }(X \\
\geq 22,6705)\end{array}$ & 1 & 5,9 \\
\hline $\begin{array}{l}\text { Good(20,1835 } \\
\leq X \quad< \\
22,6705)\end{array}$ & 13 & 76,5 \\
\hline $\begin{array}{l}\text { Enough } \\
(17,6965 \leq X \\
<20,1835)\end{array}$ & 3 & 17,6 \\
\hline $\begin{array}{l}\text { Bad(15,2095 } \\
\leq X \quad< \\
17,6965)\end{array}$ & - & - \\
\hline $\begin{array}{l}\text { Very Bad }(X \\
\leq 15,2095)\end{array}$ & - & - \\
\hline
\end{tabular}

minimal score gained from 14 students, the maximal score was gained by 23 students, the median is 18,86 , the modus was 18 and for the standard deviation was 2,487 .

The score above can be interpreted appropriately with 5 cognitive categories or the knowledge that achieve based on the gain score below:

\begin{tabular}{|l|l|}
\hline Categories & Score \\
\hline Very Good & $\mathrm{X} \geq \mathrm{M}+1,5 \mathrm{SD}$ \\
\hline Good & $\begin{array}{l}\mathrm{M}+0,5 \mathrm{SD} \leq \mathrm{X}<\mathrm{M}+1,5 \\
\mathrm{SD}\end{array}$ \\
\hline Enough & $\begin{array}{l}\mathrm{M}-0,5 \mathrm{SD} \leq \mathrm{X}<\mathrm{M}+0,5 \\
\mathrm{SD}\end{array}$ \\
\hline Bad & $\begin{array}{l}\mathrm{M}-1,5 \mathrm{SD} \leq \mathrm{X}<\mathrm{M}-0,5 \\
\mathrm{SD}\end{array}$ \\
\hline Very Bad & $\mathrm{X} \leq \mathrm{M}-1,5 \mathrm{SD}$ \\
\hline
\end{tabular}

(Source: Azwar, 2011:163, cit Ria Fitri

Lestari 2012)

Explanation

$$
\begin{array}{ll}
\mathrm{M} & =\text { Mean } \\
\mathrm{SD} & =\text { Standard deviation }
\end{array}
$$

The result of the interpretation score of posttest appropriate with the 5 cognitive categories that presented in the table below:

The result of the post-test can be shown in the histogram below:

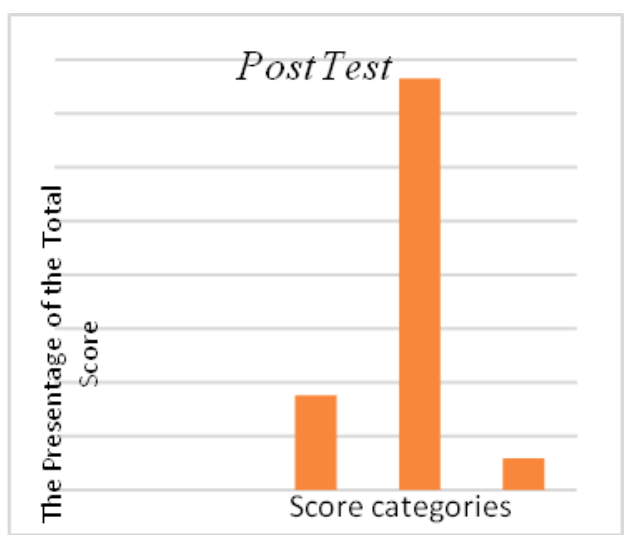

Based on the result of post-test interpretation score in the table and the histogram above, it seen that the domain cognitive of the students to the Shorof after giving the treatment in learning Shorof by using card game media, the highest score in the chart was gained in the very good category with the frequency and percentage 1 student, in the amount of 5,9 and the lowest was in enough category score with the frequency and percentage 3 and 17,6, while the good' category getting the dominant frequency and percentage, that were 13 students with 76,5 . 
The second result of the test both pretest or posttest were given to the same sample is shown in the same histogram as follows:

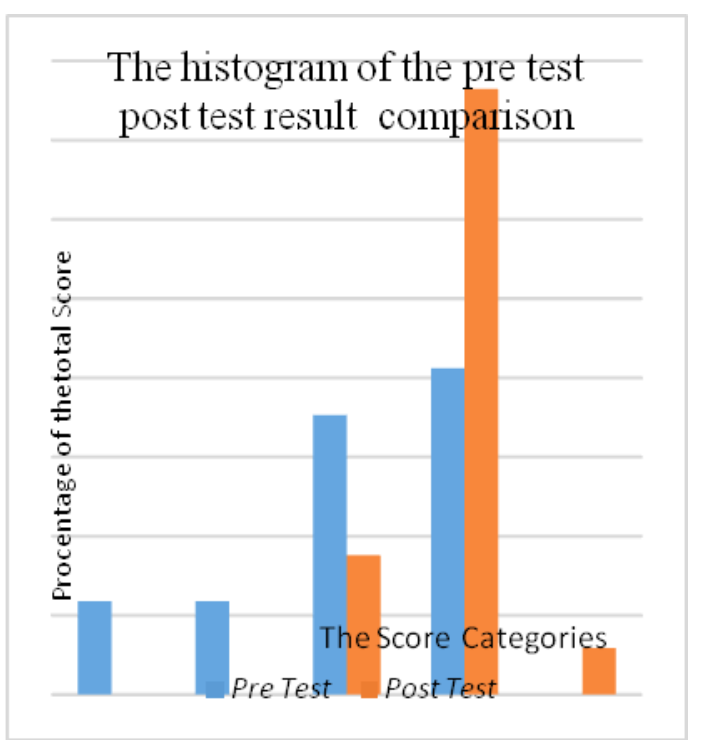

In the histogram, the comparison of the pre-test- post-test result above, there is the difference where the result of pre-test show in the gain of very bad- good categories. Whereas, the result of the post-test show in the gain of enough- very good categories.

Even though there is the difference between the result of pre-test and post-test activity through the display of the comparison between pre-test and post-test above. But, it cannot be decided yet that Karf game media has an effect to the students' knowledge in Shorof because it not knowing yet the level of significance that show the effect of it treatment experiment.

Thus, for knowing whether there is or not the effect of the treatment, the comparison of before after the treatment and the significance to the next step is doing the analysis of testing the hypothesis data for knowing whether there is or not the effect of a treatment to the research sample.
The analysis of the hypothesis that used in this research used paired sample t-test. Taking the decision by this t-test is:

- Ho is rejected: if $\mathrm{t}$-count $>\mathrm{t}-$ table or sig $<0,05$ so the Karf game media effective in learning Shorof

- Ho is accepted: if $\mathrm{t}$-count $<\mathrm{t}$ table or sig $>0,05$ so Karf game media is not effective in learning Shorof

Based on the table, the result of t-test analysis shown that sig. (2-tailed) $<0,05$, ttable for 17 sample was 1,753 . Whereas the $t-$ count showed that $-3,255$. T-table negative show that the curve calculation area in the left side. So, this is the curve that shows the $t$ count that decided the hypothesis:

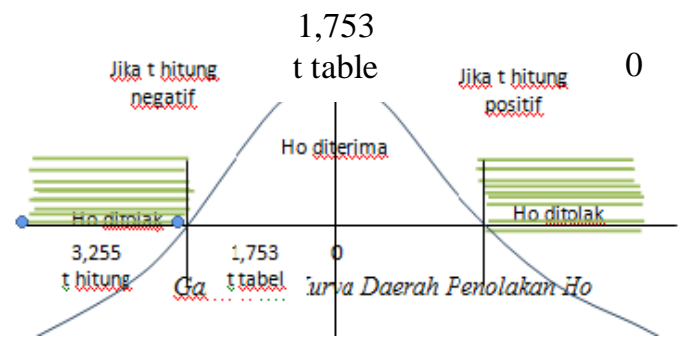

Figure 1. The area of Ho rejection curve

The curve shown that $\mathrm{t}$ - count in the left of ho shading area is rejected, so the hypothesis is ho is rejected, t-count 3,255 > ttable 1,735 or sig. 2-tailed $0,0005<0,05$ so the Karf game media is effective in learning Shorof. Thus, there is significance or effectiveness of Karf game media in learning Shorof to the 2016 PBA students on 4 semesters.

There are improvement and comparison score that gotten from the pre-test 
and post-test. Furthermore, in the result of post-test the cognitive category of the students are improving from the lowest category, Karf game media can be used for repeating the Shorof material and learn it again. Then, the use t-test above can use for taking the hypothesis and explaining the effectiveness of Karf game media in learning Shorof and it can be approved by using the analysis of the previous hypothesis. So it can be said that they are appropriate and the visual media is the card with the picture that can smoothen the understanding by elaborating the structure and organization and strengthen the memory (Arsyad, 2016:89).

\section{CONCLUSION}

Learning by using media is a challenge of creativity of the teacher in delivering the material to the students. A teacher must optimal in delivering the material, so the material can be understood and memorized easily for the students. Learning media by using card can be used by the Arabic Education' teacher in delivering the material especially the rule of Arabic material that is Shorof which in this material there are so many memorizations so this media can use for memorizing the rule of Shorof easily. Based on the research that conducted, it approved that this media can help the students in memorizing the rule of Shorof. But this media still has the the weaknesses and must be developed again from the contain moreover the compatibility or the interest of the students to the card game media, especially in this digital era where there are so many people more interest with the imaginative game in cyberspace, online and it packing in cell phone application or computer that contains games that conservatives and need a presence in the real. This is a task and challenge for the teacher in developing a learning media and make the students interest. Besides this media good and effective it also can make the students interesting to use it.

\section{REFERENCES}

A.R, Syamsudin dan Vismaia, S. D. (2015).

Metode Penelitian Pendidikan Bahasa. Bandung: Rosda.

Arikunto. (2013). Prosedur Penelitian: Suatu Pendekatan Praktik. Jakarta: Rineka Cipta.

Arsyad, A. (2012). Media Pembelajaran. Jakarta: Rajagrafindo Persada.

Dale, E. (1969). Audio Visual Methods in Teaching. New York.

Degeng, I. N. S. (1993). Media Pendidikan. Malang: FIP IKIP Malang.

Faturrohman, M. (2015). Model-model Pembelajaran. Yogyakarta: Ar-ruzz Media.

Gani, H. (n.d.). Perubahan Bentuk Kata dalam Bahasa Arab (Suatu Analisa Hubungan antara Tashrif dan Morfologi). Dosen Fakultas Tarbiyah IAIN Raden Intan Lampung.

Hamalik, O. (1994). Media Pendidikan, cetakan ke-7. Bandung: PT. Citra Aditya Bakti.

Hermawan, A. (2012). Metodologi Pembelajaran Bahasa Arab. Bandung: Rosda.

Mahyudin dan Aziz Fachrurrozi. (2016). Pembelajaran Bahasa Asing Tradisional \& Kontemporer. Jakarta: Rajagrafindo Persada. 
Rahmasari, P. (2016). Perbandingan Hasil

Belajar Mahasiswa Sebelum dan

Sesudah Proses Belajar Aktif

Menggunakan Kartu Anatomi Gigi

(KABANOGI) (Kajian pada Mahasiswa

Angkatan 2014 Program Studi

Pendidikan Dokter Gigi di Universitas

Muhammadiyah Yogyakarta). PSPDG.

FKIK. UMY.

Sudjana, N. \& Rivai, A. (1992). Media

Pengajaran. Bandung: CV. Sinar Baru.

Sukmadinata, N. S. (2012). Metode Penelitian

Pendidikan. Bandung: Rosda. 